\title{
Parental socioeconomic influences on filial educational outcomes in Scotland: patterns of school-level educational performance using administrative data
}

\author{
Christopher James Playford, Vernon Gayle, Roxanne Connelly \& Susan \\ Murray
}

To cite this article: Christopher James Playford, Vernon Gayle, Roxanne Connelly \& Susan Murray (2016) Parental socioeconomic influences on filial educational outcomes in Scotland: patterns of school-level educational performance using administrative data, Contemporary Social Science, 11:2-3, 183-202, DOI: 10.1080/21582041.2016.1172728

To link to this article: http://dx.doi.org/10.1080/21582041.2016.1172728
ఠ
(c) 2016 The Author(s). Published by Informa UK Limited, trading as Taylor \& Francis Group
Submit your article to this journal $₫$

View related articles $\sqsubset$

Citing articles: 1 View citing articles ๘
Published online: 16 May 2016.

III Article views: 599

View Crossmark data 


\title{
Parental socioeconomic influences on filial educational outcomes in Scotland: patterns of school-level educational performance using administrative data
}

\author{
Christopher James Playford $^{\mathrm{a} *}$ (D), Vernon Gayle ${ }^{\mathrm{b}}$ (D), Roxanne Connelly ${ }^{\mathrm{c}}$ (D) and Susan Murray ${ }^{\mathrm{d}}$ \\ ${ }^{a}$ Administrative Data Research Centre - Scotland, University of Edinburgh, Edinburgh, UK; ${ }^{b}$ School of \\ Social and Political Science, University of Edinburgh, Edinburgh, UK; ${ }^{c}$ Department of Sociology, University \\ of Warwick, Coventry, UK; ${ }^{d}$ School of Health Sciences, University of Stirling, Stirling, UK
}

(Received 30 November 2015; accepted 28 March 2016)

\begin{abstract}
In Britain there have been manifest changes in the management and organisation of education, but despite these developments there are still persistent inequalities in pupils' educational outcomes. These inequalities are consequential because school qualifications are known to influence both pupils' immediate continuation in education, and their later educational and occupational outcomes. The Scottish school system is similar to the system in England and Wales but there are a distinctive set of qualifications. From the mid-1980s until 2013 the final years of compulsory schooling led up to Standard Grade qualifications. Standard Grades were similar to the General Certificates of Secondary Education (GCSEs) and are worthy of detailed sociological examination because they were the first major branching point in the Scottish education system. A specialist dataset using administrative records was constructed for this project. The dataset comprises young people who undertook Standard Grades in Scottish schools between 2007 and 2011, who were members of the Scottish Longitudinal Study (SLS). We analyse pupils' subject-area outcomes using a latent variable modelling approach, and explore characteristics associated with the membership of latent educational groups. The analyses uncovered four main latent educational groups. One group had very positive outcomes and pupils were generally more socially advantaged; another group had very poor outcomes and were generally more socially disadvantaged. There were two 'middle' groups, which both had similar moderate overall Standard Grade outcomes, but notably different subject-area-level outcomes. We conclude that during school hours these pupils are unlikely to be found drinking Iron Brew WKD in their local parks or at home playing on their Xbox; however, they are also unlikely to be filling out university application forms in the next couple of years.
\end{abstract}

Keywords: Education; inequality; social stratification; latent class analysis; Scotland

\section{Introduction}

In Britain, there have been manifest changes in the management and organisation of education, and this has resulted in changes in both the curriculum and qualifications. Despite these developments, there are still persistent inequalities between pupils in their educational outcomes. These inequalities are consequential because school qualifications are known to influence both pupils' immediate continuation in education, and their later educational and occupational outcomes.

*Email: chris.playford@ed.ac.uk 
The United Kingdom of Great Britain and Northern Ireland comprises four constituent territories, of which England is the largest. Each of the four territories has separate responsibilities for education. Raffe (2000) asserts that the education and training systems within the UK exhibit two striking features. First, while they differ in a few important respects they are similar in many others, and share recognisably 'British' features. Second, the systems are politically and functionally interdependent, and are shaped by common socioeconomic and political factors. The school education systems within the four territories are far more similar to each other than they are to the education systems in other nation states.

Scotland moved to a system of comprehensive education in the mid-1960s (Murphy, 2015). Standard Grades were the first major branching point in the Scottish education system. Standard Grades are similar to the General Certificates of Secondary Education (GCSEs) which are the standard qualifications in other parts of the UK. Raffe, Brannen, Croxford, and Martin (1999) asserted that Standard Grades performed similar roles to GCSEs as the main predictor of post-age 16 destinations in education, and were also valued in the labour market. Therefore, we consider that school Standard Grade outcomes are worthy of detailed sociological examination.

From 1984 and until 2013, the final years of compulsory schooling in Scotland led up to Standard Grade qualifications. Standard Grades, like GCSEs in England, Wales and Northern Ireland, are ungrouped subject-based qualifications. There were over 30 different Standard Grade subjects. Each pupil usually undertook a maximum of seven or eight individual Standard Grade subjects, and each subject was awarded a grade on a seven-point scale (Raffe et al., 1999). The ungrouped and subject-based nature of the qualifications coupled with the grading scheme meant that there was no single recognised overall measure of Standard Grade attainment.

This presents a challenge for undertaking research on Standard Grade outcomes, and to address this challenge we take the innovative step of exploring patterns of subject-level outcomes through a latent variable modelling approach. This paper is original because it links administrative data from the Scottish Qualifications Authority (SQA) (covering school qualification outcomes from 2007 to 2011) for individual pupils with parental information from the Scottish Longitudinal Study (SLS).

\section{Theorising ordinary young people}

Studying the social lives and educational experiences of 'ordinary kids' is currently in vogue within the sociology of youth. ${ }^{1}$ Some earlier studies have focused on 'ordinary kids' (see, e.g. Brown, 1987; Jenkins, 1983; Pye, 1988), but they are now very dated. An emerging theme within this current phase of youth research is that the experiences of 'ordinary kids' have largely been absent from contemporary accounts of education. The omission of the bulk of young people with unspectacular educational outcomes has led to the deployment of the term 'missing middle' (see Roberts, 2012).

On the topic of 'ordinary' pupils and unspectacular educational outcomes, we are reminded of Phil Brown's pithy statement that there is an invisible majority of ordinary pupils who neither leave their names engraved on the school honours board nor gouged into the tops of their desks (Brown, 1987). Roberts $(2012$, p. 22) appeals to youth researchers to better document the experiences of ordinary young people through the analysis of large-scale datasets. The current paper seeks to improve understanding of the social composition of these potential 'middle' groups and further develops the work of three recent papers.

Analysing data from the British Household Panel Survey, Connelly, Murray, and Gayle (2013) explored the middle ground between pupils who were educationally successful and pupils who were unsuccessful. They identified a group of pupils with 'middle' levels of school 
GCSE attainment, and drawing on the panel element of the survey (i.e. repeated contacts with the same young people) they examined this group's activities in early adulthood. They compared this 'middle' group's education and economic activities with both more and less educationally successful peers. The 'middle' group differed in their economic activities in early adulthood, but notably made the transition from education into employment earlier.

Following on from this research, Gayle, Murray, and Connelly (2016) undertook a similar analysis using the Youth Cohort Study of England and Wales (YCS) which is a specialist youth dataset. The overall message was that educational inequality persisted in school GCSE outcomes throughout the 1990s and into the early 2000s. They reported that the overall pattern of school examinations has been one of increasing performance, but GCSE attainment remained highly stratified. In general, young males had worse outcomes than young females. There were also some marked differences in outcomes for pupils from the main minority ethnic groups. A striking result was the impact of parental socioeconomic positions, and to a lesser extent other variables measuring the young person's home environment.

In a more recent paper, Playford and Gayle (2016) analysed a single cohort of pupils from the YCS using a latent variable approach. They identified substantively interesting patterns of schoollevel GCSE outcomes that would be concealed in analyses of overall measures, or analyses of outcomes within individual GCSE subjects. The modelling process uncovered four distinctive latent educational groups. One latent group was characterised by good GCSE outcomes, and another latent group was characterised by poor GCSE outcomes. There were two latent groups with middle or moderate GCSE outcomes. These two latent groups had similar levels of overall (or agglomerate) outcomes, but one group had better outcomes in science GCSEs and the other had better outcomes in arts GCSEs.

This current paper uses contemporary Scottish data to further investigate the concept of 'middle' levels of school educational outcomes using a latent variable approach. The theoretical aim of the paper is to make a contribution to the current debate on the educational experiences and outcomes of 'ordinary' young people growing up in contemporary Britain using large-scale representative data.

\section{Data}

A specialist dataset using administrative records was constructed for this project (SLS Project Number 2014_005). ${ }^{2}$ The dataset comprises young people undertaking Standard Grades in Scottish schools between 2007 and 2011 who were members of the SLS. The SLS is a large-scale representative sample of the Scottish population which links Census records (from 1991, 2001 and 2011) to other administrative data resources (see Boyle et al., 2009). Raab (2013) provides details of the SQA data that have been linked to the SLS.

This dataset of linked SLS and SQA records provides an important research resource for studying Scottish young people and their educational outcomes. This specialised dataset plugs a gap left by the discontinuation of the Scottish School Leavers Survey (see Croxford, 2009). The wider SLS data structure provides parental and household information, although there are fewer relevant variables than would ordinarily be available within a specialist youth survey.

There are no school-level or Local Authority-level indicators in the linked SQA data. Therefore, it is only possible to undertake single-level (i.e. pupil-level) analyses. There have been a wealth of studies which have explicitly investigated the hierarchical nature of education (for a review, see Connelly, Sullivan, \& Jerrim, 2014). Studies that have examined the influence that school-level and individual-level factors have on educational attainment have demonstrated that the majority of variation in attainment is at the pupil-level (OECD, 2007; Reynolds, Sammons, Stoll, Barber, \& Hillman, 1996; Sammons, 1999). For example, Rasbash, Leckie, 
Pillinger, and Jenkins (2010) estimated that up to $80 \%$ of variance in school educational attainment can be attributed to the pupil level.

The Programme for International Student Assessment (PISA) provides valuable insights. Analyses of PISA data confirm that little of the variation in pupils' attainment in Scotland is associated with the ways in which schools differ. Most of the variation is connected with how children differ, and who you are in Scotland is far more important than what school you attended (OECD, 2007). Whilst we recognise the potential limitations of the absence of school and Local Education Authority indicators, pupil-level analyses make an important contribution to the understanding of educational outcomes.

\section{Measuring standard grade outcomes}

Measuring education and educational qualifications is a complex endeavour as there is no single agreed-upon way to categorise educational qualifications (see Gayle, Connelly, \& Lambert, 2015b; Lambert, Prandy, \& Bottero, 2007; Schneider, 2010, 2011). Standard Grades comprised a mixture of assessed coursework and examinations (Scottish Qualifications Authority, 2009). Standard Grades were assessed separately by subject, and a subject-specific Standard Grade was awarded. Pupils typically studied for around seven or eight Standard Grades over the final two years of compulsory education (Brisard \& Menter, 2008).

In the period covered by the data, there were more than 30 different Standard Grade subjects available throughout Scotland. There were no compulsory or specified sets of Standard Grades for which a pupil must study, although in some earlier periods certain subjects such as Mathematics, English and a Foreign Language were compulsory (Brisard \& Menter, 2008; Croxford, 1994a; Gavin, 2003). Pupils and parents were given a large degree of choice over which subjects a pupil studied. These choices were made under the guidance of teachers and within the constraints of the subjects offered by the pupil's school. The subjects selected were also constrained by the combination of subjects allowed by the school timetable (Croxford, 1994a, 1994b). An example of the choices available to pupils at one school (Knightswood Secondary School in Glasgow) is depicted in Figure 1.

Each Standard Grade subject studied was awarded an individual grade on a seven-point scale, the highest being grade 1, and the lowest grade 7. To give all pupils access to Standard Grade courses, the examinations were offered at three levels. The highest was Credit, followed by General and Foundation. Only Pupils who took the Credit level could attain the highest grades of 1 or 2. Pupils who took the General examination could attain a maximum grade of 3, and pupils who took the Foundation examination could attain a maximum grade of 5 (Gamoran, 1996). Because Standard Grades were ungrouped, subject-based and graded on a seven-point scale there was no single obvious method of summarising a pupil's overall Standard Grade performance.

In Scottish secondary school league tables, schools were typically ranked by the number of Standard Grade Credit awards (i.e. grades 1-2) gained by pupils (Bryce \& Humes, 2003). Government reports have focused on charting the number of pupils who gained Credit level grades, or the number of pupils who gained grades 1-3 (Anderson et al., 2004). Researchers have also been interested in documenting the number of pupils who gained Standard Grades at grades 1-3, particularly when attempting to make comparisons with the number of pupils who gained GCSE grades $\mathrm{A}^{*}$ to $\mathrm{C}$ in the rest of the UK (Anderson et al., 2004). In England, five or more GCSEs at grades $\mathrm{A}^{*}$ to $\mathrm{C}$ are a well-recognized benchmark employed in official statistics and social research (Leckie \& Goldstein, 2009). There is no similar benchmark in Scotland.

Researchers in Scotland have sometimes used the number of Credit passes or point score measures (see, e.g. Croxford, Iannelli, \& Shapira, 2007) as 'agglomerate' measures in order to 


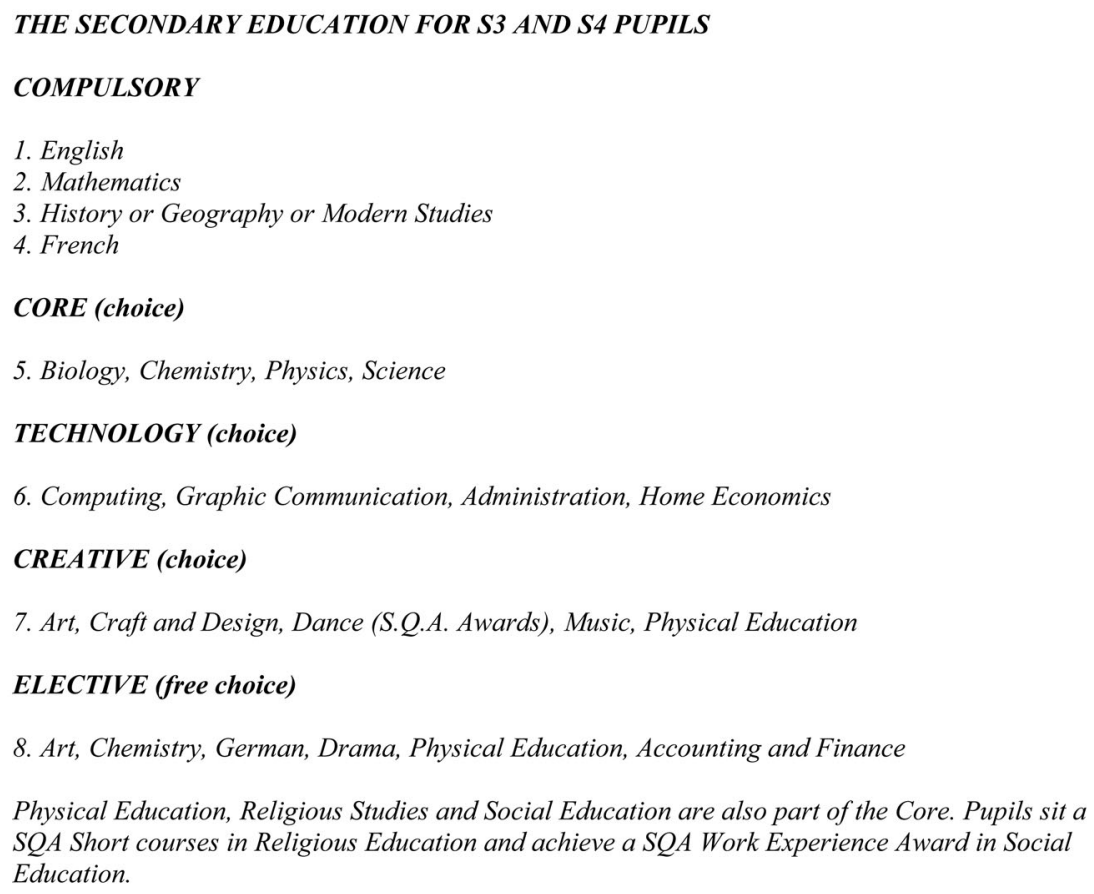

Figure 1. Example of Standard Grade subjects provided by Knightswood Secondary School, Glasgow. Source: http://www.knightswoodsecondary.org.uk/curriculum.htm accessed 7th October 2015.

describe a pupil's overall school Standard Grade outcomes. Table 1 reports some agglomerate measures for our analytical sample.

Figure 2 illustrates some choices and outcomes for a hypothetical set of pupils. The figure depicts the differences in both subjects studied and grades attained, and indicates the complexity of reducing these results to a single, substantively meaningful, agglomerate measure. The central challenge of the current paper is developing a methodological strategy to handle the messiness and complexity of individual pupil's school Standard Grade outcomes.

We adopt the terminology 'outcomes' to reflect the fact that Standard Grades are a confection of pupil choices, parental choices, teachers' decisions and institutional constraints and opportunities (e.g. the organisation of the school's timetable), and the pupil's resulting performance in the

Table 1. Agglomerate measures of Standard Grade outcomes.

\begin{tabular}{ll}
\hline Summary measures & \\
\hline 0 Standard Grade Credit Passes (grades 1-2) & $27 \%$ \\
1-4 Standard Grade Credit Passes (grades 1-2) & $40 \%$ \\
5+ Standard Grade Credit Passes (grades 1-2) & $32 \%$ \\
Mean Standard Grades Points Score (a) & 32.5 \\
Mean Number of Standard Grades Studied (b) & 6.2 \\
Mean Standard Grade Points Score per Standard Grade Studied (a/b) & 5.3 \\
Mean number of Standard Grade Credit Passes (grades 1-2) & 3.0
\end{tabular}

Source: SLS, $n=9032$. 


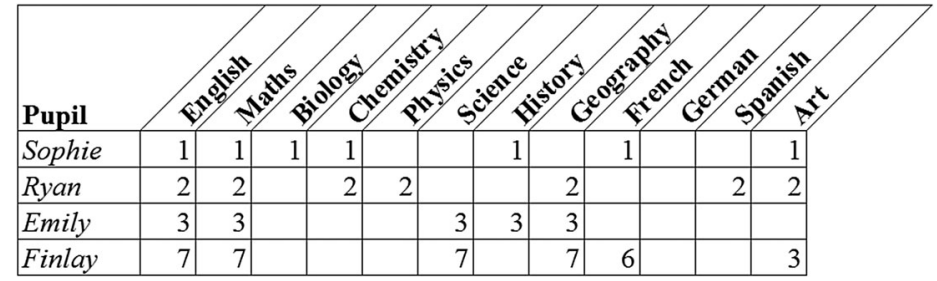

Figure 2. Example of variation in Standard Grade subject-level outcomes for a set of hypothetical pupils.

Standard Grade subjects that they are examined for. Given the large number of subjects and potential subject combinations, a process of categorisation is essential to operationalise the analysis. Table 2 lists the major subject groupings into which individual subjects have been classified. These broadly follow the modes of study outlined by the Scottish Consultative Council on the Curriculum (for details, see Gavin, 2003, p. 463).

\section{Latent variable models}

Latent class models relate a set of observed (usually categorical) variables to a set of latent or unmeasured classes (Becker \& Yang, 1998; McCutcheon, 1987, 1996, 2002). Latent class models explore the patterning of categorical outcomes across a number of observed measures. These models provide a multivariate approach to analysing complex arrays of inter-related categorical data, and offer great potential for the analysis of school Standard Grade outcomes. Gaining a Credit pass is a quality standard and a good indicator of participation in post-compulsory education (Tinklin, 2003). Therefore, pupils' subject-area Standard Grade outcomes were classified as a series of binary outcomes, where a Credit pass equals 1 , and a non-Credit pass equals 0 .

Latent class models are appropriate as a means of modelling highly correlated observed variables. Table 3 reports the correlations between Credit level passes in the 7 main subject-area groupings. For example, gaining a Credit pass in Mathematics is highly correlated with gaining a Credit pass in Sciences (0.81) but the correlation between gaining a Credit pass in Sciences and a Credit pass in English is weaker (0.66).

Table 2. Year S4 school Standard Grade subjects.

\begin{tabular}{llc}
\hline $\begin{array}{l}\text { Subject } \\
\text { groups }\end{array}$ & \multicolumn{1}{c}{ Standard Grades } & $\begin{array}{c}\text { Number of pupils } \\
\text { gaining grades 1-7 }\end{array}$ \\
\hline English & English & 7725 \\
Mathematics & Mathematics & 6959 \\
Sciences & Biology; Chemistry; Physics; Science & 6479 \\
Humanities & Classical Studies; Contemporary Social Studies; Economics; & 7527 \\
& $\quad$ Geography; History; Latin; Modern Studies; Religious Studies & 5761 \\
Languages & French; Gaidhlig; Gaelic (Learner); German; Italian; Spanish; & 3840 \\
Creative Arts & Urdu & Art; Drama; Music \\
Other & Physical Education; Accounting and Finance; Administration; & 7295 \\
\multicolumn{1}{c}{ Subjects } & Computing Studies; Craft and Design; Graphic & \\
& Communication; Home Economics; Social and Vocational & \\
Total & Studies; Technological Studies; Business Management & 9032 \\
\hline
\end{tabular}

Source: SLS, $n=9032$. 
Table 3. Year S4 school standard grade outcomes: tetrachoric correlations.

\begin{tabular}{|c|c|c|c|c|c|c|c|}
\hline & English & Mathematics & Sciences & Humanities & Languages & $\begin{array}{c}\text { Creative } \\
\text { Arts }\end{array}$ & $\begin{array}{c}\text { Other } \\
\text { Subjects }\end{array}$ \\
\hline English & 1.00 & & & & & & \\
\hline Mathematics & 0.69 & 1.00 & & & & & \\
\hline Sciences & 0.66 & 0.81 & 1.00 & & & & \\
\hline Humanities & 0.70 & 0.71 & 0.76 & 1.00 & & & \\
\hline Languages & 0.68 & 0.71 & 0.71 & 0.68 & 1.00 & & \\
\hline Creative Arts & 0.47 & 0.36 & 0.37 & 0.43 & 0.43 & 1.00 & \\
\hline $\begin{array}{l}\text { Other } \\
\text { Subjects }\end{array}$ & 0.44 & 0.49 & 0.50 & 0.51 & 0.39 & 0.11 & 1.00 \\
\hline
\end{tabular}

Source: SLS, $n=9032$.

A major attraction of applying this modelling approach is that individuals can be assigned to latent classes based on the observed outcomes examined (see Bartholomew, Steele, Moustaki, \& Galbraith, 2008, p. 272). Following Playford and Gayle (2016), because the term 'class' is used within education to denote forms or classrooms, and is also used as a short-hand for social class, from this point onwards we use the term 'latent group' rather than 'latent class' to avoid confusion.

Table 4 reports the summary statistics for a series of latent group models. We have chosen to focus on the four-group model on the basis that it provides a direct comparison with the model reported by Playford and Gayle (2016). Nylund, Asparouhov, and Muthén (2007) emphasise that theory should be a central criterion when deciding on the number of groups within a latent group model. The five- and six-group models could be preferred because the adjusted BIC statistic indicates that they are more parsimonious than the four-group model. The relative scaled entropy measure ${ }^{3}$ indicates that there is a decrease in classification certainty in the five- and six-group models. The additional latent groups in the five- and six-group models are further subdivisions of the group of pupils with the highest Standard Grade outcomes.

After investigating the five- and six-group models, we are convinced that whilst they are informative, they do not greatly contribute to an improved understanding of middle outcomes. ${ }^{4}$

Table 5 reports overall Standard Grade outcome information for each latent educational group. Sixty per cent of pupils in group 1 gained no Credit passes at Standard Grade. In contrast, nearly all of the pupils in group 4 gained 5 or more Standard Grade Credit passes. Pupils in group 1 have the poorest outcomes; they gained on average less than 1 credit pass whereas those in group 4 gained 6.6 credit passes. Pupils in group 1 gained an average of 22 points and group 4 gained 46 points.

Table 4. Latent educational group models (goodness-of-fit statistics).

\begin{tabular}{lcccrcc}
\hline Model & LL & Deviance & $\Delta$ Deviance & DF & Adj. BIC & Relative scaled entropy \\
\hline 2 Group & -32886.7 & 1500.0 & - & 112 & 1588.5 & 0.85 \\
3 Group & -32418.9 & 563.9 & 936.1 & 104 & 700.3 & 0.72 \\
4 Group & -32294.8 & 315.6 & 248.3 & 96 & 499.5 & 0.70 \\
5 Group & -32243.3 & 212.7 & 102.9 & 88 & 444.0 & 0.69 \\
6 Group & -32212.8 & 151.7 & 60.0 & 80 & 430.5 & 0.63 \\
7 Group & Model did not converge & & & & \\
\hline
\end{tabular}

Source: SLS, $n=9032$. 
Table 5. Agglomerate measures of school standard grade outcomes by latent group.

\begin{tabular}{|c|c|c|c|c|c|}
\hline Latent group & $\begin{array}{c}1 \\
\text { 'Low } \\
\text { Outcomes' }\end{array}$ & $\begin{array}{c}2 \\
\text { 'Middle } \\
\text { Non- } \\
\text { Science' }\end{array}$ & $\begin{array}{c}3 \\
\text { 'Middle } \\
\text { Science' }\end{array}$ & $\begin{array}{c}4 \\
\text { 'High } \\
\text { Outcomes' }\end{array}$ & All \\
\hline $\begin{array}{l}0 \text { Standard Grade Credit Passes } \\
\text { (grades } 1-2 \text { ) }\end{array}$ & $60 \%$ & $0 \%$ & $0 \%$ & $0 \%$ & $27 \%$ \\
\hline $\begin{array}{l}\text { 1-4 Standard Grade Credit Passes } \\
\text { (grades } 1-2 \text { ) }\end{array}$ & $40 \%$ & $79 \%$ & $70 \%$ & $5 \%$ & $40 \%$ \\
\hline $\begin{array}{l}\text { 5+ Standard Grade Credit Passes } \\
\text { (grades 1-2) }\end{array}$ & $0 \%$ & $21 \%$ & $30 \%$ & $95 \%$ & $32 \%$ \\
\hline $\begin{array}{l}\text { Mean number of Standard Grade } \\
\text { Credit Passes (grades 1-2) }\end{array}$ & 0.5 & 3.4 & 3.8 & 6.6 & 3.0 \\
\hline $\begin{array}{l}\text { Mean Standard Grades Points Score } \\
\text { (a) }\end{array}$ & 22.1 & 35.9 & 36.6 & 46.2 & 32.5 \\
\hline $\begin{array}{l}\text { Mean Number of Standard Grades } \\
\text { Examined (b) }\end{array}$ & 5.3 & 6.6 & 6.5 & 7.2 & 6.2 \\
\hline $\begin{array}{l}\text { Mean Standard Grade Points Score } \\
\text { per Standard Grade Examined }(\mathrm{a} / \mathrm{b})\end{array}$ & 4.2 & 5.4 & 5.6 & 6.4 & 5.3 \\
\hline
\end{tabular}

Source: SLS, $n=9032$.

Note: All pupils gaining a Standard Grade pass at grades 1-7.

The overall Standard Grade outcomes are similar for groups 2 and 3. The majority of pupils in group $2(79 \%)$ and group $3(70 \%)$ gained $1-4$ Credit passes. Pupils in group 2 typically gained 3.4 Credit passes compared with 3.8 for pupils in group 3. Measured by points score, both group 2 and group 3 have nearly identical outcomes. These agglomerate measures strongly suggest that pupils in groups 2 and 3 have middle or moderate educational outcomes.

The results of the four-category latent group model are reported in Table 6. In this model, there are seven observed variables measuring outcomes in English, Mathematics, Sciences, Humanities, Languages, Creative Arts and Other Subjects. Each variable is binary (Credit pass equals 1 , and a non-Credit pass equals 0 ). A single categorical latent variable was estimated. Post-estimation we have ascribed a label to each of the latent groups which describes the overall substantive pattern of Standard Grade outcomes. The posterior (group) and prior (item) probabilities estimated in the modelling process are reported as percentages in Table 6 (for further details, see Bartholomew et al., 2008, p. 273). Pupils were allocated to latent educational groups through modal assignment. ${ }^{5}$

Forty-six per cent of pupils were assigned to group 1 (low outcomes), 14\% to group 2 (middle non-science), $14 \%$ to group 3 (middle science) and $27 \%$ to group 4 (high outcomes) (see Table 6). Latent group 1 have a low probability of gaining Credit passes in all subject-areas. Conversely, latent group 4 are characterised by high probabilities of Credit passes in all subject-areas. Latent groups 2 and 3 comprise pupils who have middle levels of school Standard Grade outcomes. These findings mirror the two groups of middle GCSE outcomes identified in Playford and Gayle (2016).

A striking feature of the school Standard Grade outcomes for pupils in the two middle latent groups is their relatively poor outcomes in English, Mathematics and Science (see Table 6). Fiftynine per cent of pupils in latent group 2 gained a Credit pass in English compared with $37 \%$ in latent group 3. Six per cent of pupils in latent group 2 gained a Credit pass in Mathematics compared with $27 \%$ in latent group 3. Twenty-six per cent of pupils in latent group 2 gained a Credit pass in Science compared with $54 \%$ in latent group 3. These substantive results have led us to 
Table 6. Latent group model results (Four Group Model) school standard grade outcomes - posterior probabilities and prior probabilities (reported as percentages).

\begin{tabular}{lcccc}
\hline & & 2 & 3 & \\
Latent Group & 1 & $\begin{array}{c}2 \\
\text { 'Middle } \\
\text { Non-Science' }\end{array}$ & $\begin{array}{c}\text { 'Middle } \\
\text { Science' }\end{array}$ & $\begin{array}{c}4 \\
\text { 'High Outcomes' }\end{array}$ \\
\hline $\begin{array}{l}\text { (Posterior probabilities) } \\
\quad \text { \% assigned to group }\end{array}$ & $46 \%$ & $14 \%$ & $14 \%$ & $27 \%$ \\
$\begin{array}{l}\text { (Prior probabilities) } \\
\text { English Credit }\end{array}$ & & & & \\
English Non-Credit & $4 \%$ & $59 \%$ & $37 \%$ & $83 \%$ \\
Maths Credit & $96 \%$ & $41 \%$ & $63 \%$ & $17 \%$ \\
Maths Non-Credit & $1 \%$ & $6 \%$ & $27 \%$ & $80 \%$ \\
Science Credit & $99 \%$ & $94 \%$ & $73 \%$ & $20 \%$ \\
Science Non-Credit & $2 \%$ & $26 \%$ & $54 \%$ & $90 \%$ \\
Humanities Credit & $98 \%$ & $74 \%$ & $46 \%$ & $10 \%$ \\
Humanities Non-Credit & $3 \%$ & $56 \%$ & $61 \%$ & $88 \%$ \\
Languages Credit & $97 \%$ & $44 \%$ & $39 \%$ & $12 \%$ \\
Languages Non-Credit & $1 \%$ & $28 \%$ & $18 \%$ & $73 \%$ \\
Creative Arts Credit & $99 \%$ & $72 \%$ & $82 \%$ & $27 \%$ \\
Creative Arts Non-Credit & $9 \%$ & $55 \%$ & $10 \%$ & $49 \%$ \\
Other Subjects Credit & $91 \%$ & $45 \%$ & $90 \%$ & $51 \%$ \\
Other Subjects Non-Credit & $22 \%$ & $51 \%$ & $89 \%$ & $73 \%$ \\
$n$ (based on posterior) & $78 \%$ & $49 \%$ & $11 \%$ & $27 \%$ \\
\hline
\end{tabular}

Source: SLS, $n=9032$.

Note: All pupils gaining a Standard Grade pass at grades 1-7.

theorise that latent group 2 should be ascribed the label 'middle non-science' and latent group 3 'middle science'.

Pupils in the two latent groups had more favourable outcomes in the humanities and 'other' subjects; however, their outcomes in languages were also poor. A more subtle feature was the relatively good outcomes of latent group 2 in creative arts. Outcomes in languages and creative arts were generally lower across all latent groups, and this was partially a function of fewer pupils studying these subjects (see Table 2).

\section{Investigating the characteristics of the latent educational groups}

In the next stage of the analysis, we investigated the observed characteristics associated with membership of the latent educational groups. We estimated a series of multinomial logistic regression models with a set of similar explanatory variables used by Croxford $(2009,2015)$ and Playford and Gayle (2016). ${ }^{6}$ The overall summary modelling results and some goodnessof-fit statistics are reported in Table 7.

Table 8 reports the descriptive characteristics of each of the latent groups. Membership of the latent educational groups is obviously stratified. There are notable gender differences, with more boys in latent group 1 (low outcomes). There is a strong association with parental socioeconomic position. To a lesser extent latent group membership is also structured by household type and parental education.

The results of the multinomial logistic regression model are reported in Table 9. The outcome variable is the modal latent educational group to which the pupil has been assigned. ${ }^{7}$ Model estimates have been reported with quasi-variance intervals and predictive margins. ${ }^{8}$ Ethnicity was not included in the models because of the small number of ethnic minority pupils in Scotland. 
Table 7. Likelihood ratio tests (nested models).

\begin{tabular}{lcccc}
\hline Independent variables & \multicolumn{1}{c}{ LR } & $\Delta$ DF & LR Prob. & $\begin{array}{c}\text { McFadden's } \\
\text { Adj. } R^{2}\end{array}$ \\
\hline Null & - & - & - & - \\
Null + sex & 305.3 & 3 & 0.00 & 0.01 \\
Null + sex + household type & 281.7 & 6 & 0.00 & 0.03 \\
$\begin{array}{l}\text { Null + sex + household type + parental socioeconomic } \\
\text { position (NS-SEC) }\end{array}$ & 1062.1 & 21 & 0.00 & 0.07 \\
$\begin{array}{l}\text { Null + sex + household type + parental socioeconomic } \\
\text { position (NS-SEC) + parental education }\end{array}$ & 422.5 & 15 & 0.00 & 0.09 \\
\hline
\end{tabular}

Source: SLS, $n=8466$.

Latent educational group membership varies by gender. Males were more likely than females to be in group 1 (low outcomes) compared with group 4 (high outcomes). This finding resonates with the increasingly well-known pattern of girls outperforming boys (Biggart, 2000; Younger \& Warrington, 2005). Importantly boys have lower log odds of being in latent group 2 (middle nonscience) but higher log odds of being in latent group 3 (middle science) compared with latent group 4 (high outcomes). This appears to reflect gender differences in the uptake and attainment in different subjects across the curriculum (Croxford, 1997; Croxford, Tinklin, Frame, \& Ducklin, 2003). Francis (2002) highlights the negative consequences that school subject gender differences have for future educational and employment routes. This finding is important given contemporary concerns about female participation in Science, Technology, Engineering and Mathematics (STEM) subjects in further and higher education, and female participation in associated occupations (Institute of Physics, 2013).

Croxford (2015) reports that despite a reduction in inequalities in recent decades, observable socioeconomic differences in the educational outcomes of Scottish pupils persist. In the current analysis, parental socioeconomic position is a very important source of difference between pupils. Pupils with parents in less-advantaged socioeconomic positions are more likely to be in latent group 1 (low outcomes) rather than latent group 4 (high outcomes). This finding is wholly consistent with the routinely detected relationship between parental socioeconomic position and pupils educational outcomes.

Through the application of the latent variable model, we have detected two distinctive groups with 'middle' or 'moderate' Standard Grade outcomes. An informative finding is that parental socioeconomic position affects membership of these two latent educational groups differently. Pupils with parents in the Intermediate category (NS-SEC 3) and pupils with parents in the Routine and Manual categories (NS-SEC 5-7) are more likely to be members of latent group 2 (non-science) compared with latent group 4 (high outcomes). These are the children of paramedics (NS-SEC 3), train drivers (NS-SEC 5), tyre fitters (NS-SEC 6) and road sweepers (NS-SEC 7). This finding is particularly important as these pupils have moderate outcomes in English, poor outcomes in Science and very poor outcomes in Mathematics.

Membership of latent group 3 (middle science) follows a more predictable pattern. Compared with pupils with parents in the Higher Professional category (NS-SEC 1.2), pupils with parents in all other categories are more likely to be in latent group 3 (middle science) compared with latent group 4 (high outcomes).

There is a well-established association between parental education and filial educational outcomes (Dickson, Gregg, \& Robinson, 2013; Drew, 1995; Drew, Gray, \& Sime, 1992; Ermisch \& Pronzato, 2010; Gayle, Berridge, \& Davies, 2003; Korupp, Ganzeboom, \& Van der Lippe, 2002). This association is observed in the analysis of Standard Grade subject-area outcomes. The 
Table 8. Characteristics of the latent educational groups (row percentages).

\begin{tabular}{|c|c|c|c|c|c|c|}
\hline Latent group & $\begin{array}{c}1 \\
\text { 'Low } \\
\text { Outcomes' }\end{array}$ & $\begin{array}{c}2 \\
\text { 'Middle Non- } \\
\text { Science' }\end{array}$ & $\begin{array}{c}3 \\
\text { 'Middle } \\
\text { Science' }\end{array}$ & $\begin{array}{c}4 \\
\text { 'High } \\
\text { Outcomes' }\end{array}$ & & $n$ \\
\hline \multicolumn{7}{|l|}{ Gender } \\
\hline Male & $50 \%$ & $9 \%$ & $18 \%$ & $23 \%$ & $100 \%$ & 4670 \\
\hline Female & $40 \%$ & $18 \%$ & $10 \%$ & $31 \%$ & $100 \%$ & 4362 \\
\hline \multicolumn{7}{|l|}{ Household type } \\
\hline Both parents & $40 \%$ & $14 \%$ & $15 \%$ & $31 \%$ & $100 \%$ & 6794 \\
\hline Mother only & $62 \%$ & $13 \%$ & $10 \%$ & $14 \%$ & $100 \%$ & 2125 \\
\hline Father only & $63 \%$ & $9 \%$ & $12 \%$ & $16 \%$ & $100 \%$ & 113 \\
\hline \multicolumn{7}{|c|}{ Parental socioeconomic position $(N S-S E C)^{\mathrm{a}}$} \\
\hline $\begin{array}{l}\text { 1.2 Higher } \\
\text { Professionals }\end{array}$ & $13 \%$ & $15 \%$ & $15 \%$ & $57 \%$ & $100 \%$ & 613 \\
\hline $\begin{array}{l}\text { 1.1 Large employers } \\
\text { and higher managerial }\end{array}$ & $23 \%$ & $13 \%$ & $18 \%$ & $45 \%$ & $100 \%$ & 606 \\
\hline $\begin{array}{l}2 \text { Lower managerial and } \\
\text { professional }\end{array}$ & $31 \%$ & $16 \%$ & $16 \%$ & $37 \%$ & $100 \%$ & 2402 \\
\hline 3 Intermediate & $43 \%$ & $16 \%$ & $16 \%$ & $24 \%$ & $100 \%$ & 1288 \\
\hline $\begin{array}{l}4 \text { Small employers and } \\
\text { own account }\end{array}$ & $48 \%$ & $13 \%$ & $16 \%$ & $23 \%$ & $100 \%$ & 651 \\
\hline $\begin{array}{l}5 \text { Lower supervisory } \\
\text { and technical }\end{array}$ & $58 \%$ & $11 \%$ & $14 \%$ & $17 \%$ & $100 \%$ & 805 \\
\hline 6 Semi-routine & $65 \%$ & $11 \%$ & $12 \%$ & $12 \%$ & $100 \%$ & 1329 \\
\hline 7 Routine & $71 \%$ & $10 \%$ & $10 \%$ & $11 \%$ & $100 \%$ & 772 \\
\hline \multicolumn{7}{|c|}{ Parental highest qualification ${ }^{\mathrm{b}}$} \\
\hline $\begin{array}{l}\text { First degree/higher } \\
\text { degree }\end{array}$ & $21 \%$ & $14 \%$ & $16 \%$ & $48 \%$ & $100 \%$ & 2357 \\
\hline HNC/HND & $37 \%$ & $17 \%$ & $14 \%$ & $32 \%$ & $100 \%$ & 941 \\
\hline Highers/CSYS/A-levels & $41 \%$ & $14 \%$ & $17 \%$ & $28 \%$ & $100 \%$ & 1591 \\
\hline $\begin{array}{l}\text { O Grade/Standard } \\
\text { Grade }\end{array}$ & $57 \%$ & $14 \%$ & $14 \%$ & $15 \%$ & $100 \%$ & 2779 \\
\hline $\begin{array}{l}\text { No qualifications } \\
\text { Unknown }\end{array}$ & $75 \%$ & $9 \%$ & $9 \%$ & $7 \%$ & $\begin{array}{l}100 \% \\
100 \%\end{array}$ & $\begin{array}{r}1219 \\
145\end{array}$ \\
\hline $\begin{array}{l}\text { Posterior probabilities } \\
(\%)\end{array}$ & $46 \%$ & $14 \%$ & $14 \%$ & $27 \%$ & $100 \%$ & \\
\hline Observations & 4110 & 1225 & 1287 & 2410 & & 9032 \\
\hline
\end{tabular}

Source: SLS, $n=9032$.

Note: All pupils gaining a Standard Grade pass at grades 1-7.

${ }^{a}$ Parental socioeconomic position was measured by the highest category of NS-SEC of either parent in 2001.

${ }^{\mathrm{b}}$ Parental highest qualification was measured by the highest qualification attained by either parent in 2001 .

children of better qualified parents are more likely to be in latent group 4 (high outcomes) compared with all other groups. There is a less well-established association between household type and filial educational outcomes (Drew et al., 1992; Gayle, Murray, et al., 2016). Pupils who live in lone mother households are more likely to be in latent group 1 (low outcomes) and latent group 2 (middle non-science) compared to latent group 4 (high outcomes). Membership of latent group 3 (middle science) is not significantly associated with household type.

The analyses clearly indicate that there are four distinctive latent educational groups that are characterised by differential subject-area outcomes in Scottish Standard Grades. Two of these 
Table 9. Multinomial logistic regression model results - latent educational group membership (modal assignment).

\begin{tabular}{|c|c|c|c|c|c|}
\hline & $\mathrm{B}$ & $\mathrm{SE}$ & Quasi SE & $\begin{array}{c}\text { Predictive } \\
\text { Margin (PM) }\end{array}$ & PM SE \\
\hline \multicolumn{6}{|c|}{ Latent Group 1: 'Low Outcomes'/Latent Group 4: 'High Outcomes' } \\
\hline \multicolumn{6}{|c|}{ Gender } \\
\hline Female & 0.00 & $(0.00)$ & - & 0.00 & 0.00 \\
\hline Male & $0.66 * * *$ & $(0.06)$ & - & 0.10 & 0.01 \\
\hline \multicolumn{6}{|l|}{ Household type } \\
\hline Lives with both parents & 0.00 & $(0.00)$ & 0.04 & 0.00 & 0.00 \\
\hline Lives with mother only & $0.28 * * *$ & $(0.09)$ & 0.08 & 0.04 & 0.01 \\
\hline Lives with father only & 0.37 & $(0.32)$ & 0.31 & 0.06 & 0.05 \\
\hline \multicolumn{6}{|l|}{ Parental socioeconomic position (NS-SEC) } \\
\hline 1.2 Higher professionals & 0.00 & $(0.00)$ & 0.13 & 0.00 & 0.00 \\
\hline 1.1 Large employers and higher managerial & $0.60 * * *$ & $(0.17)$ & 0.11 & 0.09 & 0.03 \\
\hline 2 Lower managerial and professional & $0.96 * * *$ & $(0.14)$ & 0.06 & 0.15 & 0.02 \\
\hline 3 Intermediate & $1.31 * * *$ & $(0.15)$ & 0.07 & 0.21 & 0.02 \\
\hline 4 Small employers and own account & $1.44 * * *$ & $(0.17)$ & 0.10 & 0.24 & 0.03 \\
\hline 5 Lower supervisory and technical & $1.83 * * *$ & $(0.17)$ & 0.10 & 0.31 & 0.03 \\
\hline 6 Semi-routine & $2.01 * * *$ & $(0.17)$ & 0.10 & 0.34 & 0.03 \\
\hline 7 Routine & $2.04 * * *$ & $(0.19)$ & 0.13 & 0.37 & 0.03 \\
\hline \multicolumn{6}{|l|}{ Parental highest qualification } \\
\hline First degree/higher degree & 0.00 & $(0.00)$ & 0.06 & 0.00 & 0.00 \\
\hline $\mathrm{HNC} / \mathrm{HND}$ & $0.69^{* * *}$ & $(0.10)$ & 0.08 & 0.11 & 0.02 \\
\hline Highers/CSYS/A-levels & $0.75^{* * *}$ & $(0.09)$ & 0.06 & 0.11 & 0.02 \\
\hline O Grade/Standard Grade & $1.47 * * *$ & $(0.09)$ & 0.06 & 0.22 & 0.02 \\
\hline No Qualifications & $2.15^{* * *}$ & $(0.15)$ & 0.13 & 0.35 & 0.02 \\
\hline Unknown & $1.15^{* *}$ & $(0.42)$ & 0.41 & 0.27 & 0.08 \\
\hline Constant & $-2.09 * * *$ & $(0.13)$ & - & - & - \\
\hline \multicolumn{6}{|c|}{ Latent Group 2: 'Middle Non-Science'/Latent Group 4: 'High Outcomes' } \\
\hline \multicolumn{6}{|c|}{ Gender } \\
\hline Female & 0.00 & $(0.00)$ & - & 0.00 & 0.00 \\
\hline Male & $-0.34 * * *$ & $(0.08)$ & - & -0.09 & 0.01 \\
\hline \multicolumn{6}{|l|}{ Household type } \\
\hline Lives with both parents & 0.00 & $(0.00)$ & 0.05 & 0.00 & 0.00 \\
\hline Lives with mother only & $0.31 * *$ & $(0.11)$ & 0.09 & 0.02 & 0.01 \\
\hline Lives with father only & 0.01 & $(0.44)$ & 0.44 & -0.02 & 0.04 \\
\hline \multicolumn{6}{|l|}{ Parental socioeconomic position (NS-SEC) } \\
\hline 1.2 Higher professionals & 0.00 & $(0.00)$ & 0.13 & 0.00 & 0.00 \\
\hline 1.1 Large employers and higher managerial & -0.05 & $(0.17)$ & 0.13 & -0.04 & 0.02 \\
\hline 2 Lower managerial and professional & 0.24 & $(0.13)$ & 0.07 & -0.02 & 0.02 \\
\hline 3 Intermediate & $0.42 * *$ & $(0.16)$ & 0.09 & -0.02 & 0.02 \\
\hline 4 Small employers and own account & 0.33 & $(0.19)$ & 0.14 & -0.04 & 0.02 \\
\hline 5 Lower supervisory and technical & $0.40 *$ & $(0.19)$ & 0.14 & -0.06 & 0.02 \\
\hline 6 Semi-routine & $0.54 * *$ & $(0.18)$ & 0.12 & -0.06 & 0.02 \\
\hline 7 Routine & $0.47 *$ & $(0.22)$ & 0.17 & -0.06 & 0.02 \\
\hline \multicolumn{6}{|l|}{ Parental highest qualification } \\
\hline First degree/higher degree & 0.00 & $(0.00)$ & 0.07 & 0.00 & 0.00 \\
\hline $\mathrm{HNC} / \mathrm{HND}$ & $0.44 * * *$ & $(0.12)$ & 0.10 & 0.02 & 0.01 \\
\hline Highers/CSYS/A-levels & $0.36^{* * *}$ & $(0.11)$ & 0.08 & -0.003 & 0.01 \\
\hline O Grade/Standard Grade & $0.85^{* * *}$ & $(0.11)$ & 0.08 & 0.003 & 0.01 \\
\hline No qualifications & $0.92 * * *$ & $(0.19)$ & 0.17 & -0.04 & 0.02 \\
\hline Unknown & -1.25 & (1.07) & 1.06 & -0.12 & 0.03 \\
\hline
\end{tabular}


Table 9. Continued.

\begin{tabular}{|c|c|c|c|c|c|}
\hline & $\mathrm{B}$ & SE & Quasi SE & $\begin{array}{c}\text { Predictive } \\
\text { Margin (PM) }\end{array}$ & PM SE \\
\hline Constant & $-1.26 * * *$ & $(0.12)$ & - & - & - \\
\hline \multicolumn{6}{|c|}{ Latent Group 3: 'Middle Science'/Latent Group 4: 'High Outcomes' } \\
\hline \multicolumn{6}{|c|}{ Gender } \\
\hline Female & 0.00 & $(0.00)$ & - & 0.00 & 0.00 \\
\hline Male & $0.88 * * *$ & $(0.07)$ & - & 0.07 & 0.01 \\
\hline \multicolumn{6}{|l|}{ Household type } \\
\hline Lives with both parents & 0.00 & $(0.00)$ & 0.05 & 0.00 & 0.00 \\
\hline Lives with mother only & 0.03 & $(0.11)$ & 0.10 & -0.02 & 0.01 \\
\hline Lives with father only & 0.29 & $(0.39)$ & 0.38 & 0.01 & 0.04 \\
\hline \multicolumn{6}{|l|}{ Parental socioeconomic position (NS-SEC) } \\
\hline 1.2 Higher professionals & 0.00 & $(0.00)$ & 0.13 & 0.00 & 0.00 \\
\hline 1.1 Large employers and higher managerial & $0.37 *$ & $(0.17)$ & 0.12 & 0.02 & 0.02 \\
\hline 2 Lower managerial and professional & $0.34 *$ & $(0.14)$ & 0.07 & -0.01 & 0.02 \\
\hline 3 Intermediate & $0.56^{* * *}$ & $(0.16)$ & 0.09 & -0.01 & 0.02 \\
\hline 4 Small employers and own account & $0.59^{* *}$ & $(0.18)$ & 0.13 & -0.01 & 0.02 \\
\hline 5 Lower supervisory and technical & $0.75 * * *$ & $(0.19)$ & 0.13 & -0.02 & 0.02 \\
\hline 6 Semi-routine & $0.79 * * *$ & $(0.18)$ & 0.12 & -0.03 & 0.02 \\
\hline 7 Routine & $0.54 *$ & $(0.22)$ & 0.17 & -0.06 & 0.02 \\
\hline \multicolumn{6}{|l|}{ Parental highest qualification } \\
\hline First Degree/Higher Degree & 0.00 & $(0.00)$ & 0.07 & 0.00 & 0.00 \\
\hline $\mathrm{HNC} / \mathrm{HND}$ & 0.21 & $(0.13)$ & 0.11 & -0.02 & 0.01 \\
\hline Highers/CSYS/A-levels & $0.53 * * *$ & $(0.11)$ & 0.08 & 0.02 & 0.01 \\
\hline O Grade/Standard Grade & $0.89 * * *$ & $(0.11)$ & 0.08 & 0.005 & 0.01 \\
\hline No Qualifications & $1.06^{* * *}$ & $(0.18)$ & 0.16 & -0.03 & 0.02 \\
\hline Unknown & 0.24 & $(0.62)$ & 0.62 & -0.03 & 0.06 \\
\hline Constant & $-1.97 * * *$ & $(0.13)$ & - & - & - \\
\hline \multicolumn{6}{|l|}{ Latent Group 4: 'High Outcomes' } \\
\hline \multicolumn{6}{|l|}{ Gender } \\
\hline Female & 0.00 & $(0.00)$ & - & 0.00 & 0.00 \\
\hline Male & 0.00 & $(0.00)$ & - & -0.08 & 0.01 \\
\hline \multicolumn{6}{|l|}{ Household type } \\
\hline Lives with both parents & 0.00 & $(0.00)$ & - & 0.00 & 0.00 \\
\hline Lives with mother only & 0.00 & $(0.00)$ & - & -0.04 & 0.01 \\
\hline Lives with father only & 0.00 & $(0.00)$ & - & -0.04 & 0.05 \\
\hline \multicolumn{6}{|l|}{ Parental socioeconomic position (NS-SEC) } \\
\hline 1.2 Higher professionals & 0.00 & $(0.00)$ & - & 0.00 & 0.00 \\
\hline 1.1 Large employers and higher managerial & 0.00 & $(0.00)$ & - & -0.08 & 0.03 \\
\hline 2 Lower managerial and professional & 0.00 & $(0.00)$ & - & -0.12 & 0.02 \\
\hline 3 Intermediate & 0.00 & $(0.00)$ & - & -0.18 & 0.02 \\
\hline 4 Small employers and own account & 0.00 & $(0.00)$ & - & -0.19 & 0.03 \\
\hline 5 Lower supervisory and technical & 0.00 & $(0.00)$ & - & -0.23 & 0.03 \\
\hline 6 Semi-routine & 0.00 & $(0.00)$ & - & -0.25 & 0.03 \\
\hline 7 Routine & 0.00 & $(0.00)$ & - & -0.25 & 0.03 \\
\hline \multicolumn{6}{|l|}{ Parental highest qualification } \\
\hline First degree/higher degree & 0.00 & $(0.00)$ & - & 0.00 & 0.00 \\
\hline $\mathrm{HNC} / \mathrm{HND}$ & 0.00 & $(0.00)$ & - & -0.11 & 0.02 \\
\hline Highers/CSYS/A-levels & 0.00 & $(0.00)$ & - & -0.13 & 0.02 \\
\hline O Grade/Standard Grade & 0.00 & $(0.00)$ & - & -0.23 & 0.02 \\
\hline No qualifications & 0.00 & $(0.00)$ & - & -0.29 & 0.02 \\
\hline Unknown & 0.00 & $(0.00)$ & - & -0.13 & 0.08 \\
\hline
\end{tabular}


Table 9. Continued.

\begin{tabular}{lccccc}
\hline & & & & Predictive \\
& B & SE & Quasi SE & Margin (PM) & PM SE \\
\hline Constant & 0.00 & $(0.00)$ & - & - & - \\
$n$ & 8466 & & & & \\
Log likelihood & -9719.59 & & & \\
McFadden's adjusted $R$-squared & 0.09 & & & \\
\hline
\end{tabular}

Source: SLS.

Note: Standard errors in parentheses.

$* p<0.05$.

$* * p<0.01$.

$* * * p<0.001$.

latent groups have middle or moderate overall Standard Grade outcomes. Pupils in these two groups have 'ordinary' or unspectacular Standard Grade outcomes.

Membership of the latent educational groups is stratified by gender, parental socioeconomic position, parental education and, to a lesser extent, household type. A gender effect has been uncovered which highlights the well-known poor performance of boys, but also illuminates a more subtle effect on outcomes in English, Mathematics and Science.

The familiar negative effects of lower parental socioeconomic position on overall Standard Grade outcomes are observed. A less-predictable association between parental socioeconomic position and membership of latent group 2 (middle non-science) was uncovered. Inadequate performance in English, Science and Mathematics is a major obstacle for these pupils, and is likely to affect their immediate and longer-term educational and occupational outcomes.

\section{Conclusion}

In a classical text in educational sociology, Lacey (1970) comments on the disappointing outcomes of working-class pupils in grammar schools. After nearly 50 years of comprehensive education in Scotland, we observed a similarly dispiriting result. There are persistent inequalities in school educational qualifications and pupils from less-advantaged backgrounds have less-favourable outcomes.

The analyses uncovered four main latent educational groups. One group had very positive outcomes and pupils in this group were generally more socially advantaged. By contrast, another group had very poor outcomes and pupils were generally more socially disadvantaged. There were two 'middle' groups, which both had moderate overall Standard Grade outcomes. Whilst these groups were similar in their agglomerate outcomes, at the subject-area level their outcomes were notably different. Latent group 2 (middle non-science) were more likely to gain a Credit pass in English, but were relatively less likely to gain Credit passes in Mathematics and Sciences. Latent group 3 (middle science) were unlikely to gain Credit passes in English and Mathematics, but were more likely to gain Credit passes in the Sciences.

The analyses make a number of contributions to both the sociology of youth and the sociology of education. First, despite differences in the Scottish education system, these results mirror the analyses of school GCSE data from England and Wales reported by Playford and Gayle (2016). Taken together these two sets of analyses indicate that there is a high degree of empirical regularity both north and south of the Scottish border. Second, the work responds to the appeal made by Roberts (2011) for researchers to use large-scale data resources to investigate the educational experiences of 'ordinary' young people. It also demonstrates that using both standard 
statistical models and more innovative techniques is beneficial. Third, the work showcases a successful use of newly available administrative educational and social data. This is especially important because no other Scottish large-scale nationally representative youth data, which includes suitable educational and socioeconomic measures, are available for this time period.

The empirical analyses also make a distinctive and useful contribution to policy debates in education, by offering a set of typologies that help to summarise and to classify pupils' school standard Grade outcomes. These typologies are important because they can directly inform current discussions on raising standards in Scottish schools, improving pupils' knowledge and developing their skills. In particular the evidence that there are hidden groups of 'ordinary' young people with different patterns of educational outcomes, and that these pupils may require assistance and encouragement in different areas of the school curriculum is important. This finding appeals to 'Getting it Right for Every Child' (GIRFEC), which is the national approach to improving the wellbeing of children and young people in Scotland, as well as the aims of the Curriculum for Excellence reforms (Kidner, 2013).

Following on from these analyses, an obvious line of inquiry in our programme work is to examine the future educational and economic activities of these two 'middle' groups, and to compare the results with the findings on English young people presented in Connelly et al. (2013). Unfortunately this is not possible in this current analysis because suitable data have not yet been collected. We envisage that when data from the next UK decennial Census are incorporated into the SLS, such analyses may become feasible.

We have shown that data on school Standard Grade outcomes are complicated and messy and that outcomes in individual subjects are highly correlated. The latent variable approach is a practicable solution to loosening this Gordian knot and has been shown to cope with the messiness of the data without resorting to over-simplification. The subject-area groupings that we have chosen broadly followed the modes of study outlined by the Scottish Consultative Council on the Curriculum. We are mindful, however, that the results partially rest on the way that these Standard Grade subject groups have been constructed. We do believe that we have chosen a sensible strategy which was informed by comparative analyses of GCSE results undertaken by Playford and Gayle (2016) and more in-depth exploratory analyses undertaken by Playford (2011). We intend to explore alternative constructions of subject groups in future methodological work. The analyses concentrated on Credit-level outcomes because they were specifically recognised within the education system and in the labour market. We are aware that alternative outcomes could have been adopted (or scoring methods employed) but their substantive interpretation would not have been as clear and immediate.

The main methodological contribution of the paper is the application of a latent variable approach, and we are confident that it is sufficiently general and flexible to be appropriate to the analysis of the new Scottish school qualifications. Standard Grades have now been replaced by the new 'National' qualifications framework (SCQF, 2015). Scottish pupils will now study these new qualifications in the final year of compulsory schooling, and unlike Standard Grades they are single-year courses. The new National qualifications are also ungrouped and awarded at the individual subject level. Schools have made different decisions regarding the number of Nationals that a pupil will study, but Kidner (2013) states that it is likely to be approximately six courses. The new Nationals will be available at different levels. National 5 is the higherlevel qualification and is roughly equivalent to a Credit pass at Standard Grade. National 4 is a lower-level qualification, roughly equivalent to a General pass at Standard Grade, and involves only continuous assessment and no formal examination (Kidner, 2013). National 4 qualifications will be graded as pass or fail; however, the National 5 qualifications will be graded from A to D (with A being the highest grade). 
Scottish pupils will undertake about six qualifications from a wide diet of options, at two different levels, which will be graded on two separate schemes. There is no reason to suspect that pupils' outcomes in individual National qualifications will not be highly correlated. It is plausible therefore that the methodological problems associated with developing overall or agglomerate measures of school Standard Grade outcomes will also pervade the new National qualifications. Therefore, we are confident that the latent variable modelling approach demonstrated in this paper provides a practicable methodological solution that will be relevant to analysing emerging data on the new Scottish qualifications.

In conclusion we return our thoughts to the current debates within the sociology of youth on 'ordinary kids'. Roberts and MacDonald (2013) argue that the social scientific focus of youth research has often been on those young people more obviously situated at the margins of society, who are at increased risk of becoming excluded or disconnected from it. They further assert that occasionally there has been direct research interest into the lives of more-advantaged young people, especially those who engage in extended periods of education. They warn that youth research is in danger of ignoring the experiences of young people who fall somewhere in-between. Through the application of a latent variable approach we have been able to cast analytical attention towards two hidden groups of young people who had 'middle' outcomes in their school Standard Grades. To paraphrase Brown's statement and to add a more contemporary and geographical orientation, we assert that during school hours these pupils are unlikely to be found drinking Iron Brew WKD in their local parks or at home playing on their Xbox; however, they are also unlikely to be filling out UCAS forms in the next couple of years.

\section{Acknowledgements}

We gratefully thank and acknowledge the support provided by staff of the Longitudinal Studies Centre - Scotland (LSCS). The LSCS is supported by the ESRC/JISC, the Scottish Funding Council, the Chief Scientist's Office and the Scottish Government. The authors alone are responsible for the interpretation of the data. Census output is Crown copyright and is reproduced with the permission of the Controller of HMSO and the Queen's Printer for Scotland. We would also like to thank the audiences at the Social Stratification Conference (Milan), the Society for Life Course and Longitudinal Studies Conference (Dublin), and the Employment Research Institute, Edinburgh Napier University for their helpful comments on presentations related to this analysis. We would also like to thank Professor Chris Dibben and colleagues at the Administrative Data Research Centre - Scotland.

\section{Funding}

This work was supported by the Economic and Social Research Council [grant number ES/L007487/1].

\section{Disclosure statement}

No potential conflict of interest was reported by the author.

\section{Notes}

1. A special issue of Sociological Research Online 2013 18(1) was devoted to this topic.

2. See http://sls.lscs.ac.uk/projects/view/2014_005/ (retrieved October 27, 2015).

3. Entropy measures the ability of a mixture model (e.g. latent variable model) to provide well separated groups (Celeux \& Soromenho, 1996).

4. The results of these models are reported in Gayle, Playford, Connelly, and Murray (2016).

5. For a fuller discussion of methods of assignment, see Heron, Croudace, Barker, and Tilling (2015), Asparouhov and Muthén (2014), Bakk, Tekle, and Vermunt (2013) and Vermunt (2010). 
6. Recent work has demonstrated the value of undertaking sensitivity analyses with alternative occupationbased measures of socioeconomic position (e.g. Gayle, Connelly, \& Lambert, 2015a; Lambert \& Bihagen, 2014). We have estimated the multinomial logistic regression models using both National Statistics Socio-Economic Classification (NS-SEC) and the Cambridge Social Interaction and Stratification Scale (CAMSIS male scale) (see Prandy, 1999). We note that when parental socioeconomic position is measured using CAMSIS it is significant in all pairs of contrasts in the multinomial logistic regression model. An identical McFadden's adjusted $R$-squared value of 0.09 is reported for the full model including CAMSIS. The results of this model are reported in Gayle, Playford, et al. (2016). Some sociologists might argue that CAMSIS is a more suitable measure of parental socioeconomic position because it is a scale and therefore will generally be more parsimonious within a statistical modelling framework. We have chosen to present the results of the models, which include NS-SEC, because this is the official measure currently used by the UK and Scottish Governments and other educational agencies. Results using NS-SEC are therefore more readily comparable with official statistics and much existing educational research. This paper develops and extends the work of Playford and Gayle (2016) which uses NS-SEC.

7. In the spirit of executing appropriate post-estimation model evaluation, we have taken the innovative step of performing a sensitivity analysis that allowed us to compare modal assignment with proportional assignment. The proportional assignment approach was recently advocated as a practicable alternative to modal assignment by Heron et al. (2015). We are confident that in this particular analysis both assignment approaches generally place pupils in the same latent educational groups. There is a strong level of agreement between the two assignment approaches (84\%). If the allocation made by each method had been undertaken randomly (but with probabilities equal to the overall proportions), we would expect the two methods to agree on the assignment of $30 \%$ of the pupils. We calculated a Kappa value of 0.77 which Landis and Koch (1977) suggest should be interpreted as 'substantial'. We are mindful that the similarity of the results using these two methods could not have been assumed a priori. Therefore, undertaking the sensitivity analysis, despite being time consuming, has been methodologically insightful.

8. For a detailed description of quasi-variance estimation see Gayle and Lambert (2007). For an extended discussion of reporting statistical models, including predictive margins, see Connelly, Gayle, and Lambert (in press).

\section{Notes on contributors}

Christopher James Playford is Research Fellow in Social Science Research (Data Analysis and Statistics) at the University of Edinburgh, UK. He is interested in modelling family background measures and educational attainment with a substantive interest in inequality and disadvantage. He specialises in the secondary analysis of large-scale survey and administrative data.

Vernon Gayle is Professor of Sociology and Social Statistics at the University of Edinburgh, UK. His work involves the statistical analysis of large-scale and complex social science datasets including both social surveys and administrative data resources. The analysis of longitudinal (i.e. repeated contacts) data is an area of specialist expertise. The main substantive focus of his work is social stratification with particular interests in the sociology of youth and youth transitions, education and sport.

Roxanne Connelly is Assistant Professor of Sociology at the University of Warwick, UK. Her work is focused in the areas of Social Stratification and the Sociology of Education. She is a specialist in quantitative research methods, particularly longitudinal data analysis. Her research has an interdisciplinary focus and integrates insights from Psychology and Sociology.

Susan Murray is Statistician and Health Researcher at the University of Stirling, UK. She has a broad research experience including, notably, the analysis of educational attainment and youth transitions in the 1990s. She is an experienced social survey analyst and has expertise in advanced quantitative methods.

\section{ORCID}

Christopher James Playford (D) http://orcid.org/0000-0002-6069-4898

Vernon Gayle (D) http://orcid.org/0000-0002-1929-5983

Roxanne Connelly (D) http://orcid.org/0000-0002-3886-1506 


\section{References}

Anderson, S., Biggart, A., Deacon, K., Furlong, A., Given, L., \& Hinds, K. (2004). 17 in 2003 - Scotland's young people: Findings from the Scottish school leavers survey. Edinburgh: Scottish Executive Education Department.

Asparouhov, T., \& Muthén, B. (2014). Auxiliary variables in mixture modeling: Three-step approaches using Mplus. Structural Equation Modeling: A Multidisciplinary Journal, 21(3), 329-341. doi:10.1080/ 10705511.2014.915181

Bakk, Z., Tekle, F. B., \& Vermunt, J. K. (2013). Estimating the association between latent class membership and external variables using bias-adjusted three-step approaches. Sociological Methodology, 43(1), 272311. doi:10.1177/0081175012470644

Bartholomew, D. J., Steele, F., Moustaki, I., \& Galbraith, J. I. (2008). Analysis of multivariate social science data. Boca Raton, FL: CRC Press.

Becker, M. P., \& Yang, I. (1998). Latent class marginal models for cross-classifications of counts. Sociological Methodology, 28(1), 293-325. doi:10.1111/0081-1750.00050

Biggart, A. (2000). Scottish school leavers: Gender and low achievement (Scottish school leavers survey: Special report II). University of Edinburgh, Centre for Educational Sociology.

Boyle, P. J., Feijten, P., Feng, Z., Hattersley, L., Huang, Z., Nolan, J., \& Raab, G. (2009). Cohort profile: The Scottish Longitudinal Study (SLS). International Journal of Epidemiology, 38(2), 385-392. doi:10. 1093/ije/dyn087

Brisard, E., \& Menter, I. (2008). Compulsory education in the United Kingdom. In D. Meatheson (Ed.), An introduction to the study of education (pp. 240-265). Oxon: Routledge.

Brown, P. (1987). Schooling ordinary kids; inequality, unemployment and the new vocationalism. London: Tavistock.

Bryce, T., \& Humes, W. (2003). Scottish secondary education: Philosophy and practice. In T. Bryce, W. Humes, T. Bryce, \& W. Humes (Eds.), Scottish education: Second edition post-devolution (pp. 37-48). Edinburgh: Edinburgh University Press.

Celeux, G., \& Soromenho, G. (1996). An entropy criterion for assessing the number of clusters in a mixture model. Journal of Classification, 13(2), 195-212. doi:10.1007/BF01246098

Connelly, R., Gayle, V., \& Lambert, P. S. (in press). Statistical modelling of key variables in social survey data analysis. Methodological Innovations Online.

Connelly, R., Murray, S., \& Gayle, V. (2013). Young people and school GCSE attainment: Exploring the 'middle'. Sociological Research Online, 18(1), 6. doi:10.5153/sro.2880

Connelly, R., Sullivan, A., \& Jerrim, J. (2014). Primary and secondary education and poverty review. York: Joseph Rowntree Foundation.

Croxford, L. (1994a). Equal opportunities in the secondary-school curriculum in Scotland, 1977-91. British Educational Research Journal, 20(4), 371-391. doi:10.1080/0141192940200402

Croxford, L. (1994b). Trends in the Scottish curriculum framework for the S3-S4 stages, 1983-1990. Scottish Educational Review, 26(2), 97-109.

Croxford, L. (1997). Participation in science subjects: The effect of the Scottish curriculum framework. Research Papers in Education, 12(1), 69-89. doi:10.1080/0267152970120105

Croxford, L. (2009). Change over time in the context, outcomes and inequalities of secondary schooling in Scotland, 1985-2005. Edinburgh: The Scottish Government.

Croxford, L. (2015). Inequalities. In D. Murphy, L. Croxford, C. Howieson, \& D. Raffe (Eds.), Everyone's future: Lessons from fifty years of Scottish comprehensive schooling (pp. 110-138). London: IOE Press.

Croxford, L., Iannelli, C., \& Shapira, M. (2007). Documentation of the youth cohort time-series datasets (ESRC Research Project on Education and Youth Transitions in England, Wales and Scotland, 19842002 (ESRC reference R00239852)). Edinburgh: UK Data Archive. Retrieved from http://doc. ukdataservice.ac.uk/doc/5765/mrdoc/pdf $/ 5765$ userguide.pdf

Croxford, L., Tinklin, T., Frame, B., \& Ducklin, A. (2003). Gender and pupil performance: Where do the problems lie? Scottish Educational Review, 35, 135-147.

Dickson, M., Gregg, P., \& Robinson, H. (2013). Early, late or never? When does parental education impact child outcomes? (IZA Discussion Paper No. 7123). Retrieved from SSRN: http://ssrn.com/abstract= 2203273.

Drew, D. (1995). 'Race', education and work: The statistics of inequality. Aldershot: Avebury.

Drew, D., Gray, J., \& Sime, N. (1992). Against the odds: The education and labour market experiences of black young people. Youth Cohort Series 19 Employment Department Training Research and Development Series, 68, 1-56. 
Ermisch, J., \& Pronzato, C. (2010). Causal effects of parents' education on children's education (ISER Working Paper Series 2010-16). The Institute for Social and Economic Research (ISER) is based in Colchester, UK. Retrieved from https://www.iser.essex.ac.uk/files/iser_working_papers/2010-16.pdf.

Francis, B. (2002). Is the future really female? The impact and implications of gender for 14-16 year olds' career choices. Journal of Education and Work, 15(1), 75-88. doi:10.1080/13639080120106730

Gamoran, A. (1996). Curriculum standardization and equality of opportunity in Scottish secondary education: 1984-90. Sociology of Education, 69(1), 1-21. doi:10.2307/2112720

Gavin, T. (2003). The structure of the secondary curriculum. In T. G. Bryce \& W. M. Humes (Eds.), Scottish education. Second edition: Post-devolution (pp. 461-470). Edinburgh: Edinburgh University Press.

Gayle, V., Berridge, D., \& Davies, R. B. (2003). Econometric analysis of the demand for higher education. Nottingham: DfES Publications.

Gayle, V., Connelly, R., \& Lambert, P. (2015a). A review of occupation-based social classifications for social research (CPC Working Paper 60). Southampton, UK: ESRC Centre for Population Change.

Gayle, V., Connelly, R., \& Lambert, P. (2015b). A review of education measures for social research (CPC Working Paper 63). Southampton, UK: ESRC Centre for Population Change.

Gayle, V., \& Lambert, P. S. (2007). Using quasi-variance to communicate sociological results from statistical models. Sociology, 41(6), 1191-1208. doi:10.1177/0038038507084830

Gayle, V., Murray, S., \& Connelly, R. (2016). Young people and school General Certificate of Secondary Education attainment: Looking for the 'missing middle'. British Journal of Sociology of Education, 37(3), 350-370. doi:10.1080/01425692.2014.935292

Gayle, V., Playford, C. J., Connelly, R., \& Murray, S. (2016). Between the NEET and the tidy - Exploring 'middle' outcomes in Scottish school qualifications (CPC Working Paper 76). Southampton, UK: ESRC Centre for Population Change.

Heron, J. E., Croudace, T. J., Barker, E. D., \& Tilling, K. (2015). A comparison of approaches for assessing covariate effects in latent class analysis. Longitudinal and Life Course Studies, 6(4), 420-434. doi:10. 14301/llcs.v6i4.322

Institute of Physics. (2013). Closing doors: Exploring gender and subject choice in schools. London: Institute of Physics.

Jenkins, R. (1983). Lads, citizens, and ordinary kids: Working-class youth life-styles in Belfast. London: Routledge.

Kidner, C. (2013). Curriculum for excellence Scottish parliament information centre (SPICe) briefing (Vol. 13/13). Edinburgh: Scottish Parliament.

Korupp, S. E., Ganzeboom, H. B., \& Van der Lippe, T. (2002). Do mothers matter? A comparison of models of the influence of mothers' and fathers' educational and occupational status on children's educational attainment. Quality and Quantity, 36, 17-42. doi:10.1023/A:1014393223522

Lacey, C. (1970). Hightown grammar: The school as a social system. Manchester: Manchester University Press.

Lambert, P. S., \& Bihagen, E. (2014). Using occupation-based social classifications. Work, Employment \& Society, 28(3), 481-494. doi:10.1177/0950017013519845

Lambert, P. S., Prandy, K., \& Bottero, W. (2007). By slow degrees: Two centuries of social reproduction and mobility in Britain. Sociological Research Online, 12(1). doi:10.5153/sro.1493

Landis, J. R., \& Koch, G. G. (1977). The measurement of observer agreement for categorical data. Biometrics, 33(1), 159-174. doi:10.2307/2529310

Leckie, G., \& Goldstein, H. (2009). The limitations of using school league tables to inform school choice. Journal of the Royal Statistical Society. Series A (Statistics in Society), 172, 835-851. doi:10.1111/j. 1467-985X.2009.00597.x

McCutcheon, A. L. (1987). Latent class analysis (Vol. 64). London: Sage.

McCutcheon, A. L. (1996). Models for the analysis of categorically-scored panel data. In U. Engel \& J. Reinecke (Eds.), Analysis of change: Advanced techniques in panel data analysis (pp. 15-34). Berlin: de Gruyter.

McCutcheon, A. L. (2002). Basic concepts and procedures in single- and multiple-group latent class analysis. In J. A. Hagenaars \& A. L. McCutcheon (Eds.), Applied latent class analysis (pp. 56-85). Cambridge: Cambridge University Press.

Murphy, D. (2015). Comprehensive schooling in Scotland, 1965-2015. In D. Murphy, L. Croxford, C. Howieson, \& D. Raffe (Eds.), Everyone's future: Lessons from fifty years of Scottish comprehensive schooling (pp. 2-38). London: IOE Press. 
Nylund, K. L., Asparouhov, T., \& Muthén, B. O. (2007). Deciding on the number of classes in latent class analysis and growth mixture modeling: A Monte Carlo simulation study. Structural Equation Modeling: A Multidisciplinary Journal, 14(4), 535-569. doi:10.1080/10705510701575396

OECD. (2007). Quality and equity of schooling in Scotland. Paris: OECD.

Playford, C. J. (2011). The role of families in the stratification of attainment: Parental occupations, parental education and family structure in the 1990s (PhD thesis). University of Stirling. Retrieved from http:// hdl.handle.net/1893/3600

Playford, C. J., \& Gayle, V. (2016). The concealed middle? An exploration of ordinary young people and school GCSE subject area attainment. Journal of Youth Studies, 19(2), 149-168. doi:10.1080/ 13676261.2015 .1052049

Prandy, K. (1999). The social interaction approach to the measurement and analysis of social stratification. International Journal of Sociology and Social Policy, 19(9), 204-236. doi:10.1108/ 01443339910788947

Pye, J. (1988). Invisible children: Who are the real losers at school? Oxford: Oxford University Press.

Raab, G. (2013). Education data available within the Scottish Longitudinal Study. SLS Technical Working Paper 6. Longitudinal Studies Centre Scotland: Edinburgh/St Andrews. Retrieved from http://sls.lscs.ac. uk/outputs/working-papers/.

Raffe, D. (2000). Investigating the education systems of the United Kingdom. In D. Phillips (Ed.), The education systems of the United Kingdom (pp. 9-28). Oxford: Symposium Books.

Raffe, D., Brannen, K., Croxford, L., \& Martin, C. (1999). Comparing England, Scotland, Wales and Northern Ireland: The case for 'home internationals' in comparative research. Comparative Education, 35(1), 9-25. doi:10.2307/3099464

Rasbash, J., Leckie, G., Pillinger, R., \& Jenkins, J. (2010). Children's educational progress: Partitioning family, school and area effects. Journal of the Royal Statistical Society: Series A (Statistics in Society), 173(3), 657-682. doi:10.1111/j.1467-985X.2010.00642.x

Reynolds, D., Sammons, P., Stoll, L., Barber, M., \& Hillman, J. (1996). School effectiveness and school improvement in the United Kingdom. School Effectiveness and School Improvement, 7(2), 133-158. doi: $10.1080 / 0924345960070203$

Roberts, S. (2011). Beyond 'NEET' and 'tidy' pathways: Considering the 'missing middle' of youth transition studies. Journal of Youth Studies, 14(1), 21-39. doi:10.1080/13676261.2010.489604

Roberts, S. (2012). I just got on with it: The educational experiences of ordinary, yet overlooked, boys. British Journal of Sociology of Education, 33(2), 203-221. doi:10.1080/01425692.2011.649832

Roberts, S., \& MacDonald, R. (2013). Introduction for special section of sociological research online: The marginalised mainstream: Making sense of the 'missing middle' of youth studies. Sociological Research Online, 18(1), 21. doi:10.5153/sro.2929

Sammons, P. (1999). School effectiveness: Coming of age in the 21st century. Management in Education, 13 (5), 10-13. doi:10.1177/089202069901300504

Schneider, S. (2011). Measuring educational attainment (Survey Question Bank: Topic Overview 6). Retrieved from http://www.surveynet.ac.uk/sqb/topics/education/sqb_education_schneider.pdf

Schneider, S. L. (2010). Nominal comparability is not enough: (In-)Equivalence of construct validity of cross-national measures of educational attainment in the European Social Survey. Research in Social Stratification and Mobility, 28(3), 343-357. doi:10.1016/j.rssm.2010.03.001

Scottish Qualifications Authority. (2009). Marks into grades: A review of the underlying issues (Research Report 6). Edinburgh: Scottish Qualifications Authority.

SCQF. (2015). Scottish national qualifications - SCQF Levels and Timelines. Retrieved from http://www. scqf.org.uk/content/files/Old20Vs20New20(low20res)20-20Updated20July202013.pdf

Tinklin, T. (2003). Gender differences and high attainment. British Educational Research Journal, 29(3), 307-325. doi:10.1080/01411920301854

Vermunt, J. K. (2010). Latent class modeling with covariates: Two improved three-step approaches. Political Analysis, 18(4), 450-469. doi:10.1093/pan/mpq025

Younger, M., \& Warrington, M. (2005). Raising boys' achievement (Vol. Research Report 636). London: Department for Education and Skills. 